\title{
Mendelian susceptibility to mycobacterial diseases due to complete IFNgammaR2 deficiency
}

INSERM

\section{Source}

INSERM. (1999). Orphanet: an online rare disease and orphan drug data base. Mendelian susceptibility to mycobacterial diseases due to complete IFNgammaR2 deficiency. ORPHA:319547

Mendelian susceptibily to mycobacterial diseases (MSMD) due to complete interferon gamma receptor 2 (IFN-gammaR2) deficiency is a genetic variant of MSMD (see this term) characterized by a complete deficiency in IFN-gammaR2, leading to an undetectable response to IFN-gamma, and consequently, to severe and often fatal infections with bacillus Calmette-Guérin (BCG) and other environmental mycobacteria (EM). 